\title{
Rzymskokatolickie parafie diecezji przemyskiej w dobrach Ordynacji Zamojskiej w połowie XVIII wieku ${ }^{1}$
}

ABSTRAKT: W artykule przedstawiono dzieje oraz uposażenie czterech parafii wchodzących w skład rzymskokatolickiej diecezji przemyskiej, będących jednocześnie częściami dóbr Ordynacji Zamojskiej, a mianowicie Krzeszowa, Łukowej, Potoku i Tarnogrodu. Do dóbr parafialnych zaliczano ziemię (łany, ogrody, sady, stawy), własne gospodarstwa, pańszczyznę poddanych (wymiarową i tzw. darmochy), dziesięciny i meszne (zbożowe lub pieniężne). Ukazano również podstawy funkcjonowania szpitali i bractw. Agendy te utrzymywały się przeważnie z wypłacanych czynszów oraz niewielkich nadziałów ziemskich.

SŁowa KLuczowe: diecezja przemyska, Krzeszów, Łukowa, Potok, Tarnogród, Ordynacja Zamojska, Wacław Hieronim Sierakowski.

\section{Wprowadzenie}

Północna część rzymskokatolickiej diecezji przemyskiej, będąca zarazem fragmentem ogromnych dóbr zatwierdzonej przez sejm Rzeczypospolitej w $1589 \mathrm{r}$. Ordynacji Zamojskiej², nie spotkała się jak do tej pory z szerokim zaintereso-

\footnotetext{
1 Artykuł jest częścią pracy doktorskiej pt. Uposażenie parafii w rzymskokatolickiej diecezji przemyskiej w XVIII wieku, Lublin 2017 [mps].

2 Volumina legum, t. 2, Ab anno 1550 ad annum 1609, Petersburg 1859 (dalej: VL II), s. 287. Zob. też: R. Szczygieł, Ordynacja Zamojska wobec prób lokacji ośrodków miejskich przy jej grani-
} 
waniem wśród historyków. Nie jest to wprawdzie terra incognita na mapie badań, jednakże wyniki dotychczasowych ustaleń są wysoce niewystarczające ${ }^{3}$. A materiałów, chociażby o charakterze gospodarczym, nie brakuje. Lubelskie Archiwum Państwowe posiada w swoich zbiorach niezwykle cenny zespół nr 71 zatytułowany Archiwum Ordynacji Zamojskiej ze Zwierzyńca, w którego skład wchodzi znaczna liczba inwentarzy z XVII i XVIII stulecia, doskonale oddających stosunki społeczno-gospodarcze na tym terenie. Jak dotąd ten rodzaj źródła w pełni wykorzystała jedynie Agnieszka Sidorowska ${ }^{4}$.

Omawiany obszar zamykał się zasadniczo między dwoma rzekami - Sanem od zachodu i Tanwią od północy. Ta ostatnia stanowiła jednocześnie granicę między ziemią przemyską a ziemią chełmską. W górnym biegu Tanwi, blisko ujścia do Sanu w okolicach Huty Krzeszowskiej, graniczył on na niewielkim odcinku z województwem lubelskim, a od wschodu sąsiadował z ziemią bełską, wchodzącą w skład województwa o tej samej nazwie ${ }^{5}$.

Stan posiadania Zamojskich w tej części ziemi przemyskiej koncentrował się w trzech kluczach ${ }^{6}$, a mianowicie chmieleckim, krzeszowskim (czasami nazywanym krzeszowsko-tarnogrodzkim) i zamechskim. Do tego pierwszego należały wsie Chmielek, Rakówka i Zawadka, a do drugiego: miasteczka Tarnogród i Krzeszów (pierwotnie wieś) oraz wsie Biszcza, Bukowina, Kamionka, Korchów, Księżpol, Kulno, Lipiny, Piskorowice, Płusy, Potok i Sieraków. Do trzeciego na-

cach w pierwszej połowie XVII w., „Studia Iuridica Lublinensia”, vol. 25, 2016, nr 3, s. 881-883.

Z większych publikacji należy wymienić: W. Depczyński, Tarnogród 1567-1967. Monografia historyczno-gospodarcza, Tarnogród 1970; tegoż, Parafia Tarnogród, „Nasza Przeszłość”, t. 51, 1979, s. 125-207; R. Szczygieł, Lokacja miasta i jego dzieje do końca XVI wieku, [w:] Dzieje Tarnogrodu, red. R. Szczygieł, Tarnogród 2006, s. 45-63; J. Kus, Miasto w czasach przedrozbiorowych, [w:] Dzieje Tarnogrodu, s. 65-117; T. Zarębska, Tarnogród - przykład szesnastowiecznej urbanistyki polskiej, [w:] Zamość i Zamojszczyzna w dziejach i kulturze polskiej, red. K. Myśliński, Zamość 1969, s. 203-211; M. Horn, Skład zawodowy i rozwarstwienie majątkowe Żydów tarnogrodzkich w świetle inwentarzy z lat 1650-1686, „Biuletyn Żydowskiego Instytutu Historycznego w Polsce”, t. 78, 1971, nr 2, s. 11-29; W. Depczyński, Krzeszów nad Sanem, Tarnogród 1976 [mps]; T. Bazan, Zarys dziejów gminy Potok Górny 1574-2002, Leżajsk 2003; T. Bazan, Zarys dziejów, [rec.] R. Bubczyk, „Res Historica”, t. 21, 2005, s. 173-176.

4 A. B. Sidorowska, Klucz szczebrzeski Ordynacji Zamojskiej w XVII i XVIII wieku, Lublin 2009.

${ }_{5}$ Zob. Rejestr poborowy ziemi przemyskiej z 1628 roku, wyd. Z. Budzyński, K. Przyboś, [w:] Polska południowo-wschodnia w epoce nowożytnej. Źródła dziejowe, t. I, cz. 1, Przemyśl-Rzeszów 1997, s. XXXIV-XXXV.

6 Kluczem nazywano ,zespół kilku lub kilkunastu folwarków położonych w niewielkiej od siebie odległości i pozostających pod wspólnym zarządem” (cyt. za: M. Kamler, Klucz, [w:] Encyklopedia historii gospodarczej Polski do 1945 roku, red. A. Mączak, t. 1, Warszawa 1981, s. 310). 
tomiast wsie: Zamch, Babice, Łukowa, Obsza, Różaniec, Wola Obszańska i Wola Różaniecka ${ }^{7}$.

Interesujące nas parafie łacińskie znajdowały się w Krzeszowie, Łukowej, Potoku i Tarnogrodzie. Celem niniejszego przyczynku będzie ukazanie aspektów gospodarczych funkcjonowania tam placówek duszpasterskich, a więc ich uposażenia ziemskiego, poddanych kościelnych i ich pańszczyzny oraz dziesięcin i mesznego. $\mathrm{Na}$ uboczu nie pozostaną działające tam szpitale i bractwa, również dysponujące pewnymi majątkami. Zasadniczą tematykę poprzedza krótki rys historyczny omawianych tutaj miejscowości. To pozwoli na jeszcze lepsze poznanie tego ciekawego i wciąż nie do końca zbadanego obszaru.

Podstawą źródłową do tych rozważań będą wizytacje ${ }^{8} \mathrm{z}$ połowy XVIII w. przeprowadzone osobiście przez najwybitniejszego biskupa przemyskiego Wacława Hieronima Sierakowskiego (1742-1760). W ciągu prawie dwudziestoletniej posługi biskupiej odbył on dwie wizytacje diecezji przemyskiej: pierwszą już w latach 1743-1745, a drugą, tzw. sprawdzającą, w latach 1753-1757. Dokumenty te przechowywane są w przemyskim Archiwum Archidiecezjalnym (AAPrz) i zachowały się niemalże w komplecie, gdyż na 24 księgi brakuje jedynie trzech ${ }^{9}$.

7 Rejestr poborowy ziemi przemyskiej z 1628 roku, s. LXI, 5. Autorzy tej pozycji wydawniczej nie dość, że twierdzą, iż Potok i Wola Kulińska to dwie różne włości, to jeszcze mylą na dodatek Wolę Kulińską z Wolą Brzyską. Zob. Statuta Ordynacyi Zamoyskiej od r. 1589-1848, Warszawa 1902, s. 52-53.

8 Już wcześniej zauważono, że akta wizytacyjne mają kapitalne znaczenie dla różnych badań. Zob. S. Litak, Akta wizytacyjne parafii z XVI-XVIII wieku jako źródło historyczne, „Zeszyty Naukowe Katolickiego Uniwersytetu Lubelskiego", R. 5, 1962, nr 3, s. 41-58; D. Główka, Akta wizytacji kościelnych z wieków XVI-XVIII jako źródło do historii kultury materialnej: gospodarstwo wiejskie $w$ dobrach parafialnych $w$ archidiakonacie warszawskim, [w:] Szkice $z$ dziejów materialnego bytowania społeczeństwa polskiego, red. M. Dembińska, Wrocław 1989, s. 233-254; J. Ataman, Akta wizytacji diecezji przemyskiej do końca XVIII wieku ( $w$ archiwum diecezjalnym w Przemyślu), „Archiwa, Biblioteki i Muzea Kościelne”, t. 1, 1960, z. 2, s. 32-44; M. Surdacki, Źródła normatywne kościelne jako podstawa do badań nad szpitalnictwem w Polsce przedrozbiorowej, „Roczniki Nauk Społecznych”, t. 18, 1990, z. 2: Pedagogika, s. 57-70; G. Klebowicz, Nowożytne wizytacje kościelne jako uzupetniające źródło w badaniach problemu zniszczeń i najazdów w XVII-wiecznej ziemi przemyskiej i sanockiej, „Rocznik Przemyski”, t. 51, 2015, z. 3: Historia, s. 165-176; R. Czupryk, Relacje unicko-łacińskie w świetle kanonicznych wizytacji dekanalnych (na przykładzie diecezji przemyskich obrzqdku unickiego i łacińskiego w XVIII w.), „Prace Historyczno-Archiwalne”, t. 20, 2008, s. 27-36. Mimo swojej wartości powstałych na jej gruncie monografii parafii diecezji przemyskiej jest niewiele

9 Zaginięciu uległy dwie księgi wizytacyjne z dekanatu Nowe Miasto (Bybło) oraz jedna z dekanatu Pruchnik. 
Dwie osobne księgi poświęcono dekanatowi Tarnogród ${ }^{10}$, utworzonemu na mocy dekretu Sierakowskiego 22 I 1746 r. $^{11}$ Do roku 1772 na obszarze tego właśnie dekanatu, zajmującego nieco ponad $2000 \mathrm{~km}^{2}$, działało czynnie 11 pełnoprawnych parafii ${ }^{12}$, w tym rzeczone wyżej: Łukowa, Krzeszów, Potok i Tarnogród.

\section{Rys historyczny}

Najwcześniejszą metrykę ma parafia w Krzeszowie. Samą włość dokumenty datują na co najmniej 1377 r. ${ }^{13}$ Od końca XIV stulecia aż do 1590 r., czyli momentu włączenia go przez Jana Zamojskiego do ordynacji, pozostawał on w domenie królewskiej ${ }^{14}$. W $1641 \mathrm{r}$. lokowano tutaj miasteczko (z lac. oppidum) i jako takie dotrwało ono do pierwszego rozbioru Rzeczypospolitej ${ }^{15}$. Na przestrzeni XVII w. Krzeszów, jak i sam klucz krzeszowski, często i w znacznym stopniu niszczyły czambuły tatarskie ${ }^{16}$.

Krzeszów jako parafia wyłania się w 1479 r. ${ }^{17}$ Niezwykle późne są wiadomości dotyczące kościoła. Pochodzą one dopiero z końcówki wieku XVI. Wtedy

${ }_{10}$ Archiwum Archidiecezji Przemyskiej (dalej: AAPrz), sygn. 170, Status et visitatio ecclesiarum decanatus Tarnogrodensis... 1744; sygn. 179, Acta visitationis decanatus Tarnogrodensis.. 1753.

${ }^{11}$ E. Burda, Sierakowski Wacław Hieronim z Bogusławic h. Ogończyk (1700-1780), [w:] Polski słownik biograficzny, t. 37, z. 153, Warszawa 1996-1997, s. 308.

${ }_{12}$ Zob. S. Litak, Atlas Kościoła łacińskiego w Rzeczypospolitej Obojga Narodów w XVIII wieku, Lublin 2006, s. 93, 352.

${ }_{13}$ Zbiór dokumentów małopolskich (dalej: ZDM), cz. 4, Dokumenty z lat 1211-1400, wyd. S. Kuraś, Wrocław 1969, nr 1036, s. 191.

${ }^{14}$ W rzeczywistości w rękach prywatnych majętność krzeszowska była od 1588 r. Zob. VL II, s. 267.

15 Archiwum Główne Akt Dawnych w Warszawie, Metryka Koronna (dalej: AGAD, MK), Księgi wpisów, sygn. 186, k. 282-283v (Ius Theutonicum oppido Krzeszów fundationis...). Zob. też: M. Baliński, T. Lipiński, Starożytna Polska pod względem historycznym, jeograficznym i statystycznym opisana, Warszawa 1845, s. 672. Mimo to w późniejszym czasie, w świadomości ludzkiej, Krzeszów nadal funkcjonował jako wieś. Zob. AAPrz, sygn. 64, Visitatio... 1646, s. 200 (villa Krzeszów, 1646).

16 Przykładowo, w jednym z najbardziej niszczycielskich najazdów z 1624 r. życie straciło lub uprowadzono 56 osób. Z dziewięciu łanów ostała się jedynie połowa, zaś całkowitej anihilacji uległy trzy karczmy, dwa młyny, sześć spichlerzy, folwark, cerkiew i aż 81 zagród. Zob. Archiwum Państwowe w Lublinie (dalej: APL), Archiwum Ordynacji Zamojskiej ze Zwierzyńca (dalej: AOZ), Dokumenty z XVII wieku, sygn. 91, Inwentarz majętności zamechskiej 1624, s. 22-26, 31; A. Gliwa, Kraina upartych niepogód. Zniszczenia wojenne na obszarze ziemi przemyskiej w XVII wieku, Przemyśl 2013, s. 711.

${ }_{17}$ G. Klebowicz (Organizacja parafialna diecezji przemyskiej obrzadku łacińskiego w XIVXVI wieku, Lublin 2013, s. 265) uważa, że początki krzeszowskiej parafii należy łączyć prawdo- 
to poświęcono go i nadano mu wezwanie Narodzenia NMP ${ }^{18}$. Budynek ten nie przetrwał próby czasu, toteż w 1642 r. z inicjatywy Katarzyny Zamojskiej, księżnej na Ostrogu i wdowy po Tomaszu Zamojskim, kanclerzu koronnym ( $† 1638)$, wystawiono nowy drewniany kościół pw. Narodzenia NMP, św. Jana Chrzciciela i św. Stanisława Biskupa i Męczennika. Jeszcze w tym samym roku, 25 V, poświęcił go ks. Andrzej Średziński, sufragan lwowski i prepozyt przemyski ${ }^{19}$. Dotrwał on do czasów biskupstwa Aleksandra Antoniego Fredry (1724-1734). Z jego to pozwolenia (19 X 1726 r.) rozebrano dotychczasową świątynię, a rok później, w kwietniu, zaczęto wznosić nowy kościół ${ }^{20}$. Konsekrował go biskup Sierakowski w czasie wizytacji tej parafii 11 VIII 1744 r. ${ }^{21}$

Drugą najstarszą placówką duszpasterską była Łukowa. Podobnie jak Krzeszów, początkowo włość ta wchodziła w skład dóbr królewskich. Pierwsza wzmianka o niej pochodzi z 1394 r., kiedy to Władysław Jagiełło nadał wsi prawo średzkie (odmiana prawa niemieckiego) ${ }^{22}$. Po spokojnych latach w dziejach tej miejscowości, przyszedł katastrofalny wiek XVII. Dowodem na to są ogromne zniszczenia dokonane tutaj w tym czasie przez wrogie Rzeczypospolitej wojska ${ }^{23}$.

podobnie nawet $\mathrm{z}$ końcówką wieku XIV.

${ }_{18}$ Konsekracja ta nastąpiła 20 III 1596 r. Dokonał jej ordynariusz lwowski Jan Demetriusz Solikowski. Zob. AAPrz, sygn. 158, Iura praecipua et principaliora ecclesiarum parochialium decanatus Mosticensis et Leżayscensis... in visitatione generali... a. D. 1721, s. 2047; sygn. 64, Visitatio... 1646, s. 200. Zob. też: G. Klebowicz, Wezwania kościołów parafialnych w średniowiecznej diecezji przemyskiej, [w:] Felix indiget Amicis. Studia z dziejów kultury duchowej i intelektualnej średniowiecza ofiarowane Profesorowi Krzysztofowi Ożogowi, red. W. Świeboda, M. Zdanek, Kraków 2016, s. 100.

19 AAPrz, sygn. 170, k. 1.

${ }^{20}$ Ibidem, sygn. 160, Visitatio generalis... in decanatibus Jaroslaviensi, Crosnensi, Lezayscensi, Ressoviensi... 1727, k. 108v.

${ }^{21}$ Ibidem, sygn. 170, k. 1v.

${ }^{22}$ ZDM, cz. 6, Dokumenty z lat 1386-1417, wyd. I. Sułkowska-Kuraś, S. Kuraś, Wrocław 1974, nr 1602, s. 122-125. Z analizy treści tego aktu wynika, że funkcjonowała ona już od jakiegoś czasu.

${ }^{23}$ W 1624 r. w wyniku najazdu Tatarów zniszczono w Łukowej 38 chałup, kościół i szkołę, a 183 osoby uprowadzono w jasyr. Zrabowano ponadto 91 koni. Zob. APL, AOZ, sygn. 91, s. 3-7, 30; A. Gliwa, Kraina upartych niepogód, s. 700. Z kolei w wyniku napaści tatarsko-kozackiej w 1648 r. dewastacji uległo $22 \frac{1}{2}$ łanu, dwukołowy młyn, cztery karczmy, gorzelnia i aż 80 chałup. Straty ludnościowe też były spore, gdyż w niewolę wzięto wówczas 30 osób. Przepadły także konie i bydło. Zob. Центральний Державний Історичний Архів України м. Львів (dalej: ЦДІАУЛ), фонд 13, Akta grodzkie przemyskie, опис 1, справа 1069: Inducta iuramentorum castriensium Praemisliensium 1633-1659, s. 429. Dopełnieniem tego był wypad ordyńców krymskich w 1672 r., podczas którego zniesieniu uległ tamtejszy młyn, tartak oraz szynk. Zob. A. Gliwa, Kraina upartych niepogód, s. 921. 
W źródłach parafia w Łukowej pojawia się w $1466 \mathrm{r}^{24}$ Aż do drugiej dekady XVII w. trudno jest w tej miejscowości uchwycić ślady jakiegokolwiek obiektu sakralnego, chociaż mało prawdopodobne jest, by w przeciągu 150 lat nie było tam żadnego kościoła lub przynajmniej kaplicy. Z cienia wyłania się on dopiero 8 II 1615 r., kiedy to biskup bakowski Walerian Lubieniecki, z ramienia ordynariusza przemyskiego Stanisława Siecińskiego, poświęcił świątynię nadając jej wezwanie Wniebowzięcia NMP ${ }^{25}$. Jej żywot był nadzwyczaj krótki, już bowiem w 1623 r., jak wyżej wspomniano, uległa ona zniszczeniu w wyniku najazdu tatarskiego. Niełatwo powiedzieć, kiedy powstała nowa fara. Być może nastąpiło to po niedługim czasie, gdyż w 1677 r., staraniem ówczesnego plebana, Ignacego Greglińskiego kanonika zamojskiego, gruntownie kościół odrestaurowano. Jego poświęcenie nastąpiło blisko pięćdziesiąt lat później - uroczystość ta odbyła się w końcu września $1721 \mathrm{r}^{26}$

Szesnastowiecznymi parafiami były dwie ostatnie placówki w Potoku i Tarnogrodzie. Druga z nich uważana jest za starszą, aczkolwiek pełne prawo sprawowania duszpasterstwa na powierzonym jej okręgu nadano dopiero w $1598 \mathrm{r}$.

Tarnogród założono na mocy przywileju króla polskiego Zygmunta II Augusta z 14 V 1567 r., a zasadźcą został niejaki Florian Słonka ${ }^{27}$. Zmorą pomyślnego rozwoju tego miasteczka okazały się może nie tylko wojny toczone w XVII w., ale i często wybuchające pożary ${ }^{28}$. W ciągu tego stulecia Tarnogród atakowano wprawdzie tylko trzykrotnie, lecz właśnie zajęcie go przez Siedmiogrodzian w 1657 r. doprowadziło do jego znaczącego zniszczenia ${ }^{29}$. Kolejny wiek też nie był łaskawy dla Tarnogrodu. Najpierw działania militarne związane z trzecią wojną północną (1700-1721), potem konfederacja tarnogrodzka (1715) i na koniec pożar z czerwca 1761 r., dość skutecznie hamowały rozwój tego

${ }^{24}$ AAPrz, sygn. 158, s. 2123-2124, 2146; G. Klebowicz, Organizacja parafialna, s. 269. Informacje umieszczone pod tą datą sugerują, że jej rodowód można cofnąć przynajmniej do pierwszej połowy XV w.

${ }_{25}$ AAPrz, sygn. 158, s. 2130; G. Klebowicz, Wezwania kościołów parafialnych, s. 102.

${ }^{26}$ Ibidem, sygn. 170, k. 51v.

27 AGAD, MK, Księgi wpisów, sygn. 100, k. 309-312; R. Szczygieł, Lokacje miast w Polsce XVI wieku, Lublin 1989, s. 264; tegoż, Lokacja miasta i jego dzieje, s. 47-51.

${ }^{28}$ J. Kus, Miasto w czasach przedrozbiorowych, s. 70-71. Autor wyliczył, że włość tę ogień trawił aż osiem razy.

29 AOZ, Dokumenty z XVII wieku, sygn. 56, Inwentarz majętności Xiężpolskiej z miastem Tarnogrodem 1663, s. 30; J. Kus, Miasto w czasach przedrozbiorowych, s. 112 (autor podaje błędną sygn. 65); A. Gliwa, Kraina upartych niepogód, s. 641. 
ośrodka. W kilkanaście lat później dostał się on, podobnie jak cały ten obszar, pod panowanie austriackie (1772).

Placówka duszpasterska w Tarnogrodzie powstawała etapami. Podwalinę pod nią dał wspomniany już przywilej z 1567 r., w którym naznaczono dla przyszłej parafii dwa łany oraz dziesięcinę w wysokości trzech korców żyta i owsa od każdego zasiewanego łanu. Wszystko to potwierdził dokumentem z 14 I 1598 r. nowy pan tych włości, Jan Zamojski. Kilka dni później proboszcz tarnogrodzki ks. Kasper Grochowski przekazał odnośne pismo biskupowi przemyskiemu Wawrzyńcowi Goślickiemu. Ten nie zastanawiał się długo i już 23 I wydał pozwolenie na erygowanie $\mathrm{w}$ Tarnogrodzie nowej parafii ${ }^{30}$. Jak można się zorientować, cały ten proces trwał aż 30 lat.

Pewne niejasności pojawiają się, jeżeli chodzi o ustalenie pierwszej wzmianki o samym kościele. W zasadzie wszyscy znawcy tematu mówią jednym głosem, że pierwszym takim obiektem w Tarnogrodzie był kościółek szpitalny pw. Świętego Ducha (wzmiankowany w 1569 r.), i że świątynia parafialna powstała niedługo po nim ${ }^{31}$. Jednak dwie przesłanki źródłowe mogą sugerować, że jakiś dom modlitwy, pełniący funkcję parafialną, istniał już w drugiej połowie roku 1567, a więc niedługo po wydaniu samego dokumentu lokacyjnego. Pierwszym rządcą w Tarnogrodzie mianowano ks. Alberta z Wiszni, którego wybrał, w ramach przysługującego mu prawa patronatu (z łac. ius patronatus), król Polski Zygmunt II August. Stało się to już 17 IX $1567 \mathrm{r}^{32}$, a więc zaledwie cztery miesiące po lokacji miasteczka. Interesujące jest to, że instytuowano go do kościoła pw. św. św. Stanisława i Floriana Męczenników („ad parochialem ecclesiam tituli Sanctorum Stanislai et Floriani Martyrum in oppido Tarnogrod ex cruda radice") $^{33}$. Co ciekawe, zasadźca miał na imię Florian, a na św. Floriana (4 V) przypadał jeden z trzech wyznaczonych Tarnogrodowi jarmarków ${ }^{34}$. Być może istnieje ścisły związek pomiędzy drugim patronem, a lokacją miejscowości. Niestety, jak do tej pory nie udało się, poza tą jedną wzmianką, odnaleźć innego śladu ko-

\footnotetext{
${ }^{30}$ AAPrz, sygn. 143, Liber privilegiorum ecclesiarum et aliorum fundationum... dioecesis Premislienis A.D. 1689, k. 45-46v; sygn. 158, s. 2486.

${ }^{31}$ G. Klebowicz, Organizacja parafialna, s. 272: „wzniesiono najpierw kościół szpitalny”; W. Depczyński, Parafia Tarnogród, s. 127: „,w ciągu kilku lub kilkunastu lat następnych mieszczanie (...) wybudowali drugi kościół (...) parafialny"; R. Szczygieł, Lokacja miasta i jego dzieje, s. 54 (po 1578 r.); J. Kus, Miasto w czasach przedrozbiorowych, s. 68 (wybudowany po lokacji).

32 AAPrz, sygn. 26, Acta actorum...ex annis 1566-1583, 1593-1599, s. 76. Zob. G. Klebowicz, Organizacja parafialna, s. 272.

${ }^{33}$ AAPrz, sygn. 26, s. 76.

${ }^{34}$ R. Szczygieł, Lokacja miasta i jego dzieje, s. 50.
} 
ścioła o takim wezwaniu. Prawdopodobne jest jednak, że to właśnie tej świątyni zmieniono w późniejszym czasie tytulację na Zwiastowanie NMP, św. Anny i św. Wawrzyńca ${ }^{35}$. Los tego kościoła nie był najszczęśliwszy. W oktawę Bożego Ciała w 1629 r. miasteczko, od przypadkowego wystrzału z broni, ogarnął pożar, który pochłonął dotychczasową farę ${ }^{36}$. Mieszkańcy dość krótko pozostawali bez kościoła parafialnego. W latach trzydziestych XVII w. z inicjatywy II ordynata Tomasza Zamojskiego, podkanclerzego koronnego oraz proboszczów tarnogrodzkich, wpierw ks. Melchiora Stefanidesa, a potem ks. Andrzeja Kłopockiego, wzniesiono nową konstrukcję $e^{37}$. Prace zakończono w $1636 \mathrm{r}$. i jeszcze w tym samym roku nowy obiekt poświęcił, z ramienia biskupa przemyskiego Andrzeja Szołdrskiego, ks. Zachariasz Nowoszycki, sufragan lwowski. Aktu konsekracji dokonano w końcu sierpnia, a pełne wezwanie świątyni brzmiało odtąd Przemienienia Pańskiego, Zwiastowania NMP, św. Anny, św. Andrzeja Apostoła i św. Wawrzyńca Męczennika ${ }^{38}$. Stan drewnianego kościoła z biegiem czasu nieco się nadwątlił, toteż w czerwcu 1714 r. koniecznych napraw dokonał w nim ówczesny rządca ks. Wawrzyniec Sikorski, dziekan infułat zamojski ${ }^{39}$. W tej postaci przetrwał on do czasów biskupa W. H. Sierakowskiego. Dokładnie w połowie wieku XVIII rozpoczęto budowę kolejnego, tym razem murowanego obiektu w Tarnogrodzie. Akcję tę zainicjował ks. Józef Łysakowski instalowany na proboszcza w lipcu 1749 r. W przygotowaniu i rozpoczęciu prac przy wznoszeniu kościoła w znacznej mierze pomógł VII ordynat Tomasz Antoni Zamojski, wojewoda lubelski ${ }^{40}$. Efekt tych prac ujrzał światło dzienne już w nowych realiach politycznych ${ }^{41}$.

Ostatnią omawianą tutaj parafią jest Potok. Geneza wsi, identycznie jak w przypadku Tarnogrodu, jest dość jasna. Pozwolenie na założenie osady w lasach krzeszowskich wydał w pierwszej połowie 1574 r. król Polski Henryk Walezy ${ }^{42}$. Wiek XVII, podobnie jak w przypadku pozostałych wyżej omówionych

${ }^{35}$ AAPrz, sygn. 143, k. 46v.

${ }^{36}$ Ibidem, sygn. 170, k. 32v.

${ }^{37}$ Myli się J. Kus (Miasto w czasach przedrozbiorowych, s. 68), jakoby budowę w latach 16321634 prowadził ks. Melchior Stefanides. Nie mógł tego robić, skoro swoją posługę kapłańską w Tarnogrodzie skończył w 1631 r.

38 AAPrz, sygn. 158, s. 2493. Zob. też: W. Depczyński, Parafia Tarnogród, s. 148-149.

${ }^{39}$ Ibidem, sygn. 158, s. 2506.

${ }^{40}$ Ibidem, sygn. 179, k. 109-109v.

${ }^{41}$ W. Depczyński, Parafia Tarnogród, s. 150-152.

${ }^{42}$ AAPrz, sygn. 158, s. 2071: „(...) ante annos aliquot a serenissimo Rege Henrico facultas locanda nova villae dicta Wola Kulińska in fundo atque sylvis praefecturae Krzeszoviensis nobili Iosepho Wolieński concessa illi in eadem villa advocatia seu scultetia (...)”. Zob. też: T. Bazan, 
miejsc, nie należał do najłatwiejszych. I tutaj nierzadki był widok nieprzyjacielskiego żołnierza ${ }^{43}$.

Początki parafii w Potoku, tak jak i samej miejscowości, są dobrze udokumentowane źródłowo. Przywilej na utworzenie tam placówki duszpasterskiej wydał w Wilnie 15 VI 1581 r. następca Walezego, Stefan Batory $y^{44}$. W momencie wystawienia tego aktu, kościół, wybudowany przez Józefa Wolińskiego, stał już od jakiegoś czasu w miejscu zwanym „Nawsie”"45. Nosił on wezwanie św. Jana Chrzciciela. Z konsekracją kościoła musiano czekać aż do $1611 \mathrm{r}$. Wtenczas, 11 XII, z ramienia ordynariusza przemyskiego Stanisława Siecińskiego znany już Walerian Lubieniecki, biskup bakowski, uroczyście poświęcił go pod istniejącym już wezwaniem ${ }^{46}$. Zawieruchy wojenne XVII w. nie zdołały kościoła tego w poważnym stopniu uszkodzić, skoro dopiero w czwartej dekadzie XVIII stulecia postanowiono wznieść nowy obiekt, tym razem murowany ${ }^{47}$. Roboty przy

Zarys dziejów gminy, s. 167-168. W dokumencie lokacyjnym zwała się ona Wolą Kulińską. W następnych latach określano ją także Dziewczym Potokiem. G. Klebowicz (Organizacja parafialna, s. 270) zapewne przez nieuwagę stosuje błędną nazwę Dziewiczy Potok. A. Gliwa (Kraina upartych niepogód, s. 1092, 1099) uznaje Wolę Kulińską i Potok za dwie osobne miejscowości, gdy w rzeczywistości jest to ta sama włość. Zresztą w źródłach, na które się powołuje (ЦДІАУЛ, фонд 13, Akta grodzkie przemyskie, опис 1, справа 1078, Prothocollon iuramentorum contributionum castriensium Praemisliensium 1628-1629, 1662-1678, 1711, s. 1196), jest to wyraźnie stwierdzone: „Kulińskiej Woli albo Potoku”. W dodatku na mapach dołączonych do jego publikacji obie wsie są sporo od siebie oddalone. W XVIII w. coraz częściej używano już nazwy Potok. O nazewnictwie tej wsi zob. T. Bazan, Zarys dziejów gminy, s. 192-196.

${ }^{43}$ W wyniku najazdu hord tatarskich, które zapuściły się tutaj w 1624 r., zginęła jedna osoba Fedor Pieskorowski, a dziewięć uprowadzono (wśród tych ostatnich znalazł się sołtys Zania). Zrabowano przy tym 36 koni. Zob. AOZ, sygn. 91, s. 29, 31. Siedem zagród, karczmę oraz pięć łanów zdewastowały, z kolei, wspólnie z kozakami, wojska siedmiogrodzkie pod wodzą Jerzego II Rakoczego w 1657 r. Zob. ЦДІАУЛ, фонд 13, опис 1, справа 1069, s. 1063-1064. Natomiast w 1672 r. ordyńcy spustoszyli młyn o jednym kole, karczmę, a także zabili bądź uprowadzili pięciu zagrodników. Zob. ibidem, справа 1078, s. 949.

${ }^{44}$ AAPrz, sygn. 36, Acta actorum... ex annis 1636-1639, k. 206-208v; sygn. 158, s. 2070-2077. Sygnatariuszami tego aktu byli m.in. wojewoda wileński Mikołaj Radziwiłł, kasztelan wileński Eustachy Wołłowicz, kasztelan trocki Krzysztof Radziwiłł i wojewoda podlaski Mikołaj Kiszka.

${ }_{45}$ T. Bazan (Zarys dziejów gminy, s. 189, 194) twierdzi, że tenże Woliński wznosił świątynię w latach 1581-1583.

46 AAPrz, sygn. 170, k. 17.

${ }^{47}$ Ibidem, k. 17v, sygn. 179, k. 127-128, 129. Prace rozpoczęły się w 1743 r. jeszcze za życia plebana potockiego ks. Grzegorza Jastrzębskiego, kanonika kijowskiego. Po jego śmierci (przed 23 I 1744 r.) robotami krótko kierował jego sukcesor ks. Walenty Smarzyński, kanonik zamojski (do 30 VI 1745 r.), a po nim - ks. Franciszek Wierzbowski, duchowny pochodzący z diecezji chełmskiej. Na nową świątynię złożyli się: Kazimierz Grabiński, cześnik nurski i dzierżawca Potoku, jego brat Franciszek, rzekomy podczaszy wileński, posesor wsi Naklik i Lipin oraz Teresa z Mie- 
nim trwały do połowy lat pięćdziesiątych. Druga wizytacja biskupa Sierakowskiego z 1754 r. opisuje kościół już jako „,nowo murowany z kaplicami dwiema, zakrystią i skarbcem murowanymi" ${ }^{\prime 48}$.

\section{Uposażenie w ziemię}

Najważniejsza dla funkcjonowania parafii była oczywiście ziemia. Już w najwcześniejszych przywilejach i fundacjach zapisy o niej gwarantowały żywotność danej placówki w dalszej perspektywie czasowej. Na obszarze diecezji przemyskiej dominowały parafie mające takiego „poświętnego” od jednego do dwóch łanów pola. Podobna tendencja utrzymywała się nie tylko na tym obszarze, ale i w całej Rzeczypospolitej ${ }^{49}$. Nie inaczej wyglądało to w przypadku czterech opisywanych tutaj parafii. W połowie XVIII w. stan posiadania ziemskiego w stosunku do pierwotnych donacji (przynajmniej jeśli chodzi o Krzeszów i Łukową) był nieco większy, a przyczyniły się do tego późniejsze zapisy ofiarodawców. Niemożliwe jest dzisiaj dokładne określenie położenia pól, należących do parafii w okresie staropolskim. Obecnie nic nie daje historykom adnotacja mówiąca o tym, że np. jeden łan w Potoku znajdował się między polem prebendarza szkaplerznego a polem „Pączkowskie”, które niegdyś nazywano „Słomowskie”50. O ile wtedy orientowano się, gdzie leży dana nieruchomość, o tyle dzisiaj jest to całkowicie niezrozumiałe.

Łany te przeznaczano do różnych celów. Siano na nich zboże (przeważnie owies i żyto, rzadziej pszenicę i jęczmień), wydzierżawiano ich kawałki poddanym plebańskim w zamian za pańszczyznę i czynsz lub zostawiano je zwyczajnie odłogiem. Na ich powierzchnię składały się niekiedy łąki, pastwiska, lasy, duże stawy i niewielkie sadzawki. To na nich budowano domostwa plebańskie, folwarki i inne gospodarstwa ${ }^{51}$. Poza tym nierzadko sami rządcy najmowali nadziały ziemskie od innych podmiotów parafialnych, tak jak w Łukowej, gdzie

\footnotetext{
chowskich, żona ówczesnego VII ordynata Tomasza Antoniego Zamojskiego, starosty płoskirowskiego. Dwaj pierwsi przeznaczyli na budowę kościoła 6000 złp, zaś żona ordynata - 3000 złp.

${ }^{48}$ Ibidem, sygn. 179, k. 130v.

${ }^{49}$ M. Kowalski, Uposażenie parafii, s. 93.

${ }^{50}$ AAPrz, sygn. 170, k. $18 \mathrm{v}$.

${ }^{51}$ Ibidem, k. 2v-5, 14-14v (Krzeszów), 18v-19, 20-20v, 28v (Potok), 33v-34v, 46v (Tarnogród), 52v-54, 57, 58 (Łukowa).
} 
za pewne dobra plebani płacili po kilkanaście złotych tamtejszemu bractwu św. Anny ${ }^{52}$.

Typowe dla tego krajobrazu są ogrody i sady. Miały one różną wielkość, zwykle od kilku do kilkudziesięciu zagonów. W przypadku ogrodów sadzono na nich niezwykle popularną wówczas kapustę i inne warzywa, a także zioła. Popularnością cieszyły się również włóknodajne konopie i len. W sadach (notabene często tożsamych z ogrodami) królowały drzewa owocowe, przeważnie śliwowe ${ }^{53}$.

W stawach i sadzawkach z kolei hodowano ryby. Zbiorniki te rzadko jednak utrzymywano w należytym porządku. W tym czasie stanowiły one przeważnie wodopoje dla licznego drobiu gospodarczego ${ }^{54}$.

\section{Budynki gospodarcze}

Plony zrodzone z ziemi przechowywano w przystosowanych do tego obiektach gospodarczych. Ziarno zbóż wsypywano do sąsieków znajdujących się w spichlerzach, słomę i siano gromadzono w stodołach, szopach i brogach, natomiast owoce, warzywa i ich przetwory w spiżarniach, piwnicach i grubach. Do suszenia owoców służyły, umieszczone zwykle pod dachem kuchni i piekarń, specjalnie do tego przystosowane suszarnie i dymniki. Wszelaki sprzęt rolniczy (pługi, brony, wozy) trzymano w szopach lub wozowniach.

Obok wytwórczości roślinnej, równie ważne było prowadzenie hodowli zwierzęcej. W stajniach przetrzymywano konie, woły i krowy, w chlewach świnie, z rzadka owce czy kozy, a w kurnikach i gęśnikach - drób w postaci kur, kapłonów, gęsi, kaczek i indyków. Spotykano też pasieki oraz gołębniki, ale wizytacje tych czterech parafii nie mówią nic o prowadzeniu tego rodzaju działalności. Produkty nabiałowe trzymano w sernikach lub wspomnianych już piwnicach i grubach.

Większe kompleksy przeistoczono w folwarki, aczkolwiek pojęcie to w oczach wizytatorów, w wielu przypadkach, było równoznaczne ze zwykłym obejściem. Trudno powiedzieć, jakimi zasadami kierowali się oni nazywając jedne gospodarstwa folwarkami, a drugie nie, skoro areał ziemski poszczególnych parafii

\footnotetext{
52 Ibidem, k. 53v.

53 M. Kowalski, Uposażenie parafii, s. 96-99.

54 AAPrz, sygn. 170, k. 4. Przykładowo w Krzeszowie staw nie przynosił żadnych korzyści: „,nullum fructum”.
} 
znacząco się od siebie nie różnił. Abstrahując jednak od tego tematu, wizytatorzy opisali dwa folwarki w Krzeszowie, z których pierwszy „od plebanii położony o 10 staj, przy drodze tarnogrodzkiej”55, a drugi „o półmili za plebanią, płotami

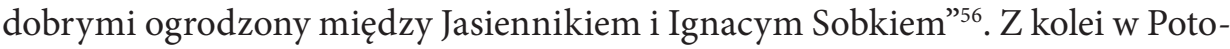
ku umiejscowiono folwark ,zaraz za drogą na boku”"57.

W gospodarstwie kościelnym ważne elementy stanowiły też młyny, karczmy i browary. W połowie XVIII w. młyny i karczmy zniknęły jednak z uposażenia tych parafii. Ich brak wyjaśniają zasadniczo dwa zjawiska. Po pierwsze, rządcom nie zależało zbytnio na utrzymywaniu młyna, skoro w przywilejach mieli oni i tak zagwarantowane mielenie swojego zboża za darmo u młynarzy dworskich (z łac. libera molitio). Tym właśnie przywilejem cieszono się w Krzeszowie i Poto$\mathrm{ku}^{58}$. Po drugie zaś, jeżeli chodzi o karczmy, to właściciele szlacheccy mocno bronili swojego monopolu na wytwarzanie, a zwłaszcza sprzedaż trunków, toteż niejednokrotnie zabraniano duchownym zajmowania się tą dziedziną. Wyjątkiem jest tutaj browar w Łukowej, który wizytacja opisywała w następujący sposób:

\begin{abstract}
„(...) ten w rogu parkanu kościelnego od południa nowo wybudowany (...) z drzewa (...). W niej sień duża, bez powały i podłogi, w której pieców dwa: jeden - gorzałczany, drugi - piwny (...). Komora na schowanie wódek (...). Ta z powałą, bez podłogi (...). Z tej komory są drzwi do izdebki dla winiarza (...). Ta z powałą i podłogą (...) pieca w sobie jeszcze niemająca (...). Słodownia (...), w której piec do suszenia słodów (...), koryto wielkie do zalewania słodów (...). Schody na górę (...) w której susznica do słodów (...). W tyle tej słodowni jest wybudowany chlew (...)" ${ }^{m 9}$.
\end{abstract}

Czy sprzedawano tam napoje alkoholowe? Nic o tym nie świadczy, aczkolwiek w rzeczywistości mogło mieć to miejsce, ponieważ, jak zauważył Dariusz Główka, „dla części rządców parafii ujawnianie tej dziedziny dochodu było niewygodne"60.

55 AAPrz, sygn. 170, k. 14v.

56 Ibidem, sygn. 179, k. 141v.

57 Ibidem, sygn. 170, k. 28v.

58 Ibidem, k. 5, 19.

59 Ibidem, k. 104-104v.

60 D. Główka, Gospodarka w dobrach plebańskich na Mazowszu w XVI-XVIII wieku, Warszawa 1991, s. 77. 
O kondycji gospodarczej parafii świadczy poniekąd stan techniczny użytkowanych budynków. A ten, zresztą jak i w całej diecezji, był daleki od zadowalającego. Nieciekawy obraz wyłaniał się w Potoku, gdzie zauważono, że: stodoły w ścianach są „miejscem zgniłe, a w dachu złe”, dwa budynki - „w ścianach spróchniałe i w dachu nadgniłe”, a obora - „w znacznej dezolacji znajduje się i zwaleniu prędkiemu podlega" ${ }^{\prime \prime}$. Słabo to wyglądało też w Tarnogrodzie. Jedną stajnię opisano tam jako $\mathrm{w}$,ścianach dużo zrujnowaną", budynek czeladny - ,stary i nadpróchniały”, wozownię - w ,ścianach miejscami znacznie zgniłą, w dachu zbutwiałą i dziurawą", piwnicę - „wodnistą", a spichlerz - w ,ścianach spróchniały, od robaków stoczony i dach nadgniły"62.

Apele Sierakowskiego o to, aby naprawić tę infrastrukturę, trafiały zazwyczaj w próżnię. Dowodem na to są protokoły wizytacyjne sporządzone dziesięć lat później, w których zanotowano w zasadzie taki sam stan rzeczy, dodając jedynie informacje o nowym spichlerzu w Tarnogrodzie ${ }^{63}$.

\section{Poddani parafialni i ich powinności}

Na wydajność gospodarstwa parafialnego pracowali poddani kościelni. W swoich powinnościach nie różnili się od pobratymców z latyfundiów szlacheckich czy królewskich. Podobnie jak tam, tak i w majątkach duchownych, byli oni warstwą mocno zróżnicowaną. Nie do końca pewny jest ich status, gdyż trudno ustalić go na podstawie realizowanych przez nich świadczeń, a o nadziałach ziemskich, dzierżawionych przez poddanych, informacji praktycznie nie ma. W wiekach wcześniejszych różnice te dało się w pewien sposób uchwycić, lecz w XVIII w. jest to już zadanie co najmniej karkołomne ${ }^{64}$. Niemniej parafie posiadały swoich poddanych, a najwięcej ich, bo aż 33, miał do swojej dyspozycji proboszcz z Krzeszowa $^{65}$. Za nim plasował się pleban potocki z 21 chłopami $^{66}$,

\footnotetext{
${ }^{61}$ AAPrz, sygn. 170, k. 28v-29; sygn. 179, k. 133v.

${ }^{62}$ Ibidem, sygn. 170, k. 46-47.

${ }^{63}$ Ibidem, sygn. 179, k. 120v.

${ }^{64}$ M. Kowalski, Uposażenie parafii, s. 174. Autor tego artykułu wyliczył, że spośród wszystkich poddanych z parafii w całej diecezji przemyskiej, kmiecie stanowili niecałe $9 \%$, a zagrodnicy 25\%. Należy dodać, że aż 780 chłopów (42\%) nie określono żadnym terminem wskazującym ich status społeczny.

${ }^{65}$ AAPrz, sygn. 170, k. 14v-15.

${ }^{66}$ Ibidem, k. 29.
} 
a dalej rządca w Łukowej (16 osób) ${ }^{67}$ i w Tarnogrodzie (13 osób) ${ }^{68}$. Zaliczano ich głównie do kmieci i zagrodników. Sądząc z imion i nazwisk (lub przezwisk) niemal wszystkich uważano za Polaków. Jedynie Iwan Koziak z Krzeszowa i Dmitro z Tarnogrodu mogli mieć pochodzenie ruskie, ale co do tego nie ma całkowitej pewności (zob. Imienny wykaz).

Imienny wykaz poddanych parafialnych w połowie XVIII w.

\begin{tabular}{|c|c|}
\hline PARAFIA & PODDANI \\
\hline Krzeszów & $\begin{array}{l}\text { Kmiecie lub zagrodnicy: Wojtek Nastula, Franciszek Waliło, } \\
\text { Franek Igras, Adam Chwałek, Jan Chwałek, Wawrzek Babiarz, Łu- } \\
\text { kasz Babiarz, Jurek Kama, Jan Ogryzek, Wojciech Ogryzek, Jakub } \\
\text { Ogon, Józef Bucon, Grzech Klus, Józef Klus, Michał Figura, Stefan } \\
\text { Chwałek, Iwan Koziak, Ogierowa wdowa, Franciszek Bucon, An- } \\
\text { drzej Babiarz, Wojciech Babiarz, Tomek Dąbek, Kazimierz Suszko, } \\
\text { Maciej Urąga, Jan Adamczyk, Mateusz Kuli, Marcin Zochara, Ko- } \\
\text { walka wdowa, Jakub Chojnacki, Kazimierz Dęmbski, Michał Tech- } \\
\text { man, Malicha wdowa, Jędrzej Łatka }\end{array}$ \\
\hline Łukowa & $\begin{array}{l}\text { Kmiecie lub zagrodnicy: Tomek Mrówka, Antoni Lęgec, Jan } \\
\text { Dyrka, Sobek Pituła, Jędrzej Borkowski, Błażej Górniak, Michał Ja- } \\
\text { błoński, Marcin Mazur, Józef Gaca, Błażej Firel, Józef Szwiec, Woj- } \\
\text { ciech Kupczyński, Pitulicha wdowa, Sobczycha wdowa, Kowalka } \\
\text { wdowa, Piszczycha wdowa }\end{array}$ \\
\hline Potok & $\begin{array}{l}\text { Kmiecie: Maciej Okoń, Adam Okoń, Jakub Śniosek, Jan Den- } \\
\text { kowski, Thomasz Kruszowiec, Antoni Wojdyła, Garbacz; kmiecie } \\
\text { (?) Maciej Szymaniuk, Wawrzyniec Gnojek, Kazimierz Gnojek, Ję- } \\
\text { drzej Znak, Maciej Znak, Jakób Bziczka, Grygiel, Sobek Zabłomi, } \\
\text { Piotr Razak, Jędrzej Zabłomi, Marcin Kotulski, Jakub Ostrowski, } \\
\text { Kostyszka wdowa, Kazimierz Gorczyca }\end{array}$ \\
\hline Tarnogród & $\begin{array}{l}\text { Kmiecie lub zagrodnicy: Józef Klecha, Majcher Sapiński, Jac- } \\
\text { ko Derb, Luka Dec, Michał Solarz, Szwędzicha wdowa, Krzysztof } \\
\text { Dostojnik, Sopelicha wdowa, Wojtek Pieniążek, Grześko, Dmitro, } \\
\text { Sebastian tkacz, Wojciech tkacz }\end{array}$ \\
\hline
\end{tabular}

Odrabianą przez nich pańszczyznę można podzielić na dwa rodzaje. Pierwszy, zamykał się przeważnie w jednym dniu w tygodniu, w czasie którego odpracowywali usadowioną na dobrach kościelnych i dzierżoną przez siebie chałupę, zagrodę, pole itp. Czynili to albo pieszo, albo, co bogatsi, sprzężajem (bydłem

${ }^{67}$ Ibidem, k. 63.
${ }^{68}$ Ibidem, k. 47. 
swoim lub plebańskim). Drugi rodzaj prac nazywał się darmochą (daremszczyzną). Wówczas to wyprawiano się na nieodpłatną posługę np. przy żniwach, sadzeniu warzyw czy stróży. Przykładowo kmieciom z Potoku nakazano, wedle inwentarza, „ogrody pleć, konopie międlić i moczyć, kapustę i jarzynę zebrać, stróżę nocną kolejno trzymać i przeręble w zimie na sadzawkach rąbać, zboże kolejno do młyna wozić, zboże na rok do Tarnogrodu dwa razy, do Krzeszowa jeden raz wywozić" 69 . Wbrew powszechnej opinii, rzadko zdarzało się, by chłopów plebańskich zmuszano do odrabiania pańszczyzny w większym wymiarze niż im pierwotnie nakazano, toteż można zaryzykować tezę, że mieli się oni lepiej od tych pracujących w dobrach świeckich.

Oprócz wykonywanych robót poddani płacili także roczne czynsze. Mówi się tutaj o drobnych kwotach w przedziale od 12 gr do 2 złp, przy czym obowiązek ten dotyczył tylko nieco ponad $30 \%$ wszystkich tutejszych kmieci-zagrodników. Ponadto uiszczali oni daniny naturalne (zamieniane niekiedy na pieniądze). W Krzeszowie część chłopów oddawała po jednym kapłonie i 12 jaj, a także półsztuki wyrobionej przez siebie przędzy ${ }^{70}$. Porównywalnie czyniono w Potoku, gdzie jeden kmieć Maciej Okoń przekazywał jedną kurę i tuzin jaj, zaś pozostali - po połowie kury i sześć jaj. Każdy z nich dostarczał na plebanię także sztukę przędzy ${ }^{71}$. Z kolei w Łukowej wszystkich zobligowano jedynie do jednej sztuki przędzy ${ }^{72}$.

\section{Dziesięciny i meszne}

Kolejnym niezwykle ważnym czynnikiem uposażeniowym były daniny zbożowe. Wyrażało się to w dziesięcinach snopowych (z łac. decima manipularis) oraz mesznym (z łac. messalia). Dziesięciny, jak sama nazwa wskazuje, charakteryzowały się oddawaniem dziesiątej części plonów przez chłopów użytkujących ziemię (najczęściej kmieci) lub zorganizowane ośrodki wiejskie takie jak folwarki czy wójtostwa ${ }^{73}$. W odróżnieniu od nich, meszne uiszczano w gotowym (wymłóconym) już ziarnie ${ }^{74}$. O ile w średniowieczu czy XVI stuleciu daniny te miały

${ }^{69}$ Ibidem, k. 29

${ }^{70}$ Ibidem, k. 14v-15.

${ }^{71}$ Ibidem, k. 29.

72 Ibidem, k. 63.

73 Z. Gloger, Encyklopedia staropolska ilustrowana, t. 2, Warszawa 1972, s. 104-107.

${ }^{74}$ Ibidem, t. 3, Warszawa 1972, s. 201. Niekiedy terminy te stosowano zamiennie, toteż czasami trudno jest jednoznacznie stwierdzić, co było dziesięciną, a co mesznym. Zob. E. Wiśniowski, 
zazwyczaj „naturalną” formę, o tyle w czasach późniejszych często zastępowano ją pieniądzem. Inna sprawa, że ordynariusze diecezji nie zawsze patrzyli na te zamiany z zadowoleniem, gdyż w tym czasie wartość pieniądza mocno spadała. W tej sytuacji świeckim (głównie szlachcie) opłacało się raczej wypłacać rządcy parafialnemu monety niż dostarczyć gotowe produkty rolne. Szczególnego przeciwnika takiej procedury źródła notują w biskupie W. H. Sierakowskim.

$\mathrm{W}$ wizytacjach znajduje się sporo informacji o tego rodzaju nadaniach. W najstarszej parafii krzeszowskiej pierwotnie trzech kmieci z tej włości oddawało dziesięcinę, potem już wszyscy kmiecie i ci, którzy otrzymali ziemię od plebana. Przywilej ten na folwarki krzeszowskie „Malinik” i „Kaczyniec”, rozciągnął, 18 XI 1664 r., III ordynat Jan „Sobiepan” Zamojski, wojewoda sandomierski. Powyższy dokument potwierdził jego siostrzeniec i następca Stanisław Koniecpolski, oboźny koronny. Sto lat później, z gospodarstw tych, proboszcz nie dostawał już jednak przyrzeczonych mu snopów zboża. Z kolei do mesznego, zobligowano chłopów katolików oraz Rusinów dzierżawiących pola „łacińskie” ze wsi Kamionka. Każdy z nich dawał żyto w wysokości połowy korca dawnej miary (z łac. mensura vetus), w której mieściło się 48 garnców (z łac. olla) ${ }^{75}$.

Bez większych incydentów należności te oddawano w Łukowej. Jeżeli chodzi o dziesięcinę, tamtejszy pleban otrzymywał ją z wójtostwa we wsi Obsza. Składała się ona z ośmiu miar (z łac. modius) tarnogrodzkich żyta i owsa przekazywanych na św. Marcina (11 XI). To samo czyniły folwarki we wsi Zamch oraz wójtostwo w Łukowej. Natomiast folwark we wsi Chmielek wypłacał z tego tytułu co roku 30 złp. Nieco problemów nastręczało meszne. O ile w Łukowej, jak się wydaje, każdy chłop, należący zarówno do dziedzica, jak i do sołtysa, regularnie odmierzał rządcy po dwa półmiarki (z łac. duo modii) żyta i owsa, to pewien opór w tej kwestii zaobserwowano we wsiach Chmielek, Obsza i Zamch. Koniec końców, zażegnano nieporozumienie i chłopi z wymienionych wsi zaczęli oddawać po jednej macy żyta (z Chmielka i Obszy - z 16 zagonów, z Zamchu - z 24 zagonów $)^{76}$.

Kolęda-meszne-stołowe na ziemiach polskich. Problem rejonizacji, [w:] Kultura średniowiecza i staropolska. Studia ofiarowane Aleksandrowi Gieysztorowi w pięćdziesięciolecie pracy naukowej, red. D. Gawin, Warszawa 1991, s. 625-638.

${ }^{75}$ AAPrz, sygn. 170, k. 4v. Ustalenie dokładnych wartości miar nasypnych z epoki staropolskiej jest dzisiaj niezwykle trudne. Sama różnorodność terminologiczna stosowana w źródłach zasługuje na osobną rozprawę. Zob. M. Kowalski, Uposażenie parafii, s. 147-155.

${ }^{76}$ AAPrz, sygn. 170, k. 54v-55. 
Ciekawiej przedstawiała się sprawa w dwóch ostatnich parafiach. W Potoku dziesięcinę wypłacano w pieniądzu. Z pól wójtowskich były to trzy grzywny, a z folwarku we wsi Naklik - pięć grzywien. W 1616 r. parafia potocka uzyskała dziesięcinę i meszne ze wsi Wola Brzyska i Wólka Łamana. Nastąpiło to za zgodą biskupa przemyskiego Stanisława Siecińskiego (wydaną 18 II), zatwierdzoną w Warszawie przez króla polskiego Zygmunta III już 12 X i później jeszcze przez króla Michała Korybuta Wiśniowieckiego (4 IV 1670 r.). Od niemal samego początku pewna kontrowersja dotyczyła 30 złp dawanych z Wólki Łamanej, do których pretensje rościł sobie prepozyt leżajski.

Spór przeniósł się do sądu. Ks. Grzegorz Jastrzębski, kanonik kijowski, rządca w Potoku wystąpił przeciwko ks. Józefowi Drozdowskiemu bożogrobcowi, prepozytowi leżajskiemu. Najpierw skarga ta trafiła do konsystorza przemyskiego (11 VI 1740 r.), a później do nuncjatury w Warszawie (9 II 1742 r.). Ta ostatnia odesłała akta sprawy do Przemyśla, a ten zawyrokował na korzyść plebana z Potoku. Duchowny ten nie miał szczęścia także do dziesięcin z Woli Brzyskiej, przywróconych mu dopiero przez dekret sądu konsystorskiego z 27 VIII $1753 \mathrm{r}$. Wysokość powinności ustalono na $30 \mathrm{złp}^{77}$.

Zróżnicowanie rzecz wyglądała z mesznym. Gotowe ziarno otrzymywano z Potoku i Zagródki - po dwie mace żyta i półtrzecie (2⿺辶1/2) owsa, ze wsi Dąbrówka - po cztery miary owsa, ze wsi Borowiny - jednego roku po macy żyta, a drugiego po macy owsa, ze wsi Brzeżowice - jednego roku po macy owsa, a drugiego po macy grochu, a od 30 zagrodników ze wsi Naklik - po macy owsa. $\mathrm{W}$ pozostałych czterech wsiach meszne płacono w pieniądzach. I tak ze wsi Szyszki - po 24 gr, ze wsi Jedlinki - po jednej grzywnie, z Wólki Łamanej - 36 gr od dwóch Polaków (z łac. duo Poloni), zaś z Woli Brzyskiej - 10 złp od chłopów katolików. Pewne nieporozumienia na tym tle zachodziły we wsi Lipiny. Tam zamiast mac żyta i owsa z 12 półłanków płacono po 18 złp. Na taką sytuację nie chciał zgodzić się wspominany już ks. Jastrzębski, zaskarżając tę formę płatności w sądzie biskupim 13 XI $1739 \mathrm{r}^{78}$

Interesująco przedstawiały się te sprawy $\mathrm{w}$ Tarnogrodzie. Zgodnie $\mathrm{z}$ przywilejem z 1567 r. z każdego łanu należącego do tego miasteczka oraz z pól wsi Bukowina, proboszcz otrzymywał po trzy korce żyta i owsa. W stosunku do włości bukowińskiej ten stan rzeczy zmienił się w 1598 r. Jan Zamojski zwolnił ją $\mathrm{z}$ danych jeszcze przez Zygmunta Augusta dziesięcin, a w zamian za to, co

\footnotetext{
77 Ibidem, sygn. 179, k. 128v.

${ }^{78}$ Ibidem, sygn. 170, k. 19v-21.
} 
roku wójt wsi Lipiny wypłacał rządcy tarnogrodzkiemu pięć grzywien. Decyzję tę zaakceptował w tym samym czasie ordynariusz przemyski Wawrzyniec Goślicki. Na św. Marcina dziesięcinę przekazywali też chłopi ze wsi Różaniec: $40 \mathrm{z}$ nich po korcu żyta i owsa, 35 osób po korcu żyta, zaś 17 zagrodników po jednej czwartej korca żyta. W drugiej dekadzie XVII w. do Tarnogrodu przyłączono wsie Jastrzębiec oraz Luchów i odtąd także stamtąd szły w ręce proboszcza zwyczajowe daniny. $Z$ problemami czyniono to w latach trzydziestych następnego stulecia w Jastrzębcu. W pewnym momencie dzierżawca tej wsi, niejaki Stanecki, cześnik sochaczewski, zaprzestał wydawania nakazanego mu zboża. Stało się to powodem wszczęcia przeciwko niemu procesu, zakończonego połowicznym tylko sukcesem. Pod koniec 1736 r. ustalono, że dziesięciny zostaną przywrócone, ale meszne w pierwotnej postaci już nie. Odtąd ich równowartość wynosiła $15 \mathrm{złp.} \mathrm{W} \mathrm{drugiej} \mathrm{wsi,} \mathrm{Luchów,} \mathrm{bezproblemowo} \mathrm{wypłacano} \mathrm{dziesięciny}$ w wysokości 80 złp, z kolei mesznego - 40 złp $^{79}$.

Rację ma W. Depczyński pisząc, że tego rodzaju uposażenie „w praktyce przysparzało wiele kłopotów, dochód z niej był nierówny i niepewny, a mieszkańcy ociągali się z jej wypłatą"80.

\section{Szpitale}

Agendami parafialnymi w staropolskich placówkach duszpasterskich były szpitale. Nie miały one wiele wspólnego z dzisiejszym pojęciem opieki zdrowotnej. Jak pisali Józef Rolle i Władysław Szumowski „szpitale w Galicji były to instytucje dawnego pokroju, przytułki, w których chory, a częściej stary i ubogi znajdował curam animae lecz nie curam corporis i dalej, że nędza, kalectwo, starość a często i choroba znajdowały przytułek w zakładach dobroczynnych wznoszonych przy kościołach albo mówiąc inaczej przy probostwach i klasztorach" Pierwsze szpitale na ziemiach polskich pojawiły się w XII i XIII w. ${ }^{82}$ Najstarszy $\mathrm{z}$ omawianych tutaj parafii mieścił się w Tarnogrodzie przy kościółku pw. Świętego Ducha. Zanotowano go w źródłach pod rokiem 1569. Potem stał on przy

${ }^{79}$ Ibidem, k. 33v-34, 49-49v.

${ }^{80}$ W. Depczyński, Parafia Tarnogród, s. 136.

${ }^{81} \mathrm{~J}$. Rolle, Zakłady dobroczynne i szpitale $w$ dawnem województwie podolskiem, „Przegląd Lekarski”, nr 17, 1867, s. 131; W. Szumowski, Galicya pod względem medycznym za Jędrzeja Krupińskiego pierwszego protomedyka 1772-1783, Lwów 1907, s. 67.

${ }^{82}$ Zob. M. Surdacki, Opieka społeczna w Polsce do końca XVIII wieku, Lublin 2015, s. 6. 
nowej świątyni szpitalnej powstałej pod koniec XVI stulecia noszącej wezwanie Świętego Ducha oraz św. Tomasza Apostoła ${ }^{83}$.

O pierwotnym budynku szpitalnym nie wiadomo nic poza tym, że istniał. Być może był to ten sam, wspomniany w wizytacji biskupa przemyskiego Jana Krzysztofa Szembeka z 1721 r., stojący dawniej po zachodniej stronie kościoła za drogą prowadzącą do Lublina ${ }^{84}$. Nowy przytułek wystawił po spaleniu poprzedniego (z łac. fatale incendium) Jan Wyszpolski, skarbnik żydaczowski, przy współpracy z proboszczem tarnogrodzkim (ks. Maciejem Pawłowiczem, dziekanem zamojskim albo ks. Walentym Józefem Paczoskim, scholastykiem zamojskim). Budowę ukończono prawdopodobnie gdzieś w końcówce lat trzydziestych XVIII w. Obiekt stanął w tym samym miejscu ,za kościołem przy Bramie Księżpolskiej”. Składał się z sieni, izby, dużej komory oraz małej stajni. Jego uposażenie stanowiły wpierw czynsze od czterech osób na ogólną sumę 291 złp i 15 gr oprocentowanych na osiem procent. Od 1669 r. kwota ta urosła do $650 \mathrm{złp}$, a jedną z takich przykładowych lokat ufundował Bartłomiej Żmijowski na dobrach piekarza Marcina na placu Różanieckim w Tarnogrodzie. Nie ma pewności, czy owe czynsze płacono w czasach Sierakowskiego. Nie wolno zapominać też o sześciu florenach dawanych przez proboszcza za najmowanie połowy łanu należącego do szpitala. Z nieruchomości użytkowanych przez ubogich trzeba wymienić jeszcze siedem ogrodów w różnych miejscach na ogólną długość jednego stajania, przyszpitalny ogród oraz sad ${ }^{85}$.

Drugim najstarszym szpitalem, po tarnogrodzkim, był przytułek w Krzeszowie. Pozwolenie na jego funkcjonowanie wydał II ordynat Tomasz Zamojski, wojewoda kijowski 20 lub 23 II 1622 r. Roborowano je następnie w księgach grodzkich przemyskich w końcu sierpnia 1636 r. ${ }^{86}$ Najważniejszym punktem tych nadań były tzw. ordynaria szpitalne, w ramach których dostarczano 14 penitencjariuszom produkty spożywcze. Składały się na nie dwa korce mąki żytnej, korzec grochu, dwa połcie mięsa, 13 kwart masła, 15 serów, achtel piwa i trzy

\footnotetext{
${ }^{83}$ AAPrz, sygn. 64, s. 205; G. Klebowicz, Organizacja parafialna, s. 271-273; W. Partyka, Opieka społeczna w Ordynacji Zamojskiej w XVII-XVIII wieku, Lublin 2008, s. 94.

${ }^{84}$ AAPrz, sygn. 158, s. 2490.

${ }^{85}$ Ibidem, sygn. 170, k. 38-38v, 48. Twierdzenie W. Partyki o tym, że jakoby wizytacje nie podają żadnych informacji o ogrodach szpitalnych w Tarnogrodzie (s. 120), jest nie do końca prawdziwe. W 1744 r. wyraźnie zaznaczono, że tamtejszy przytułek posiadał „hortis septem variis in locis iacentibus".

${ }^{86}$ Ibidem, sygn. 158, s. 2052 (20 II), sygn. 170, k. 7 (23 II); W. Partyka, Opieka społeczna, s. 48, 93.
} 
kwarty nieco tajemniczego pultium, a jeden poddany wyznaczony przez dwór musiał raz w roku przywieźć drewno dla potrzebujących oraz uporządkować szpitalny ogród. Niegdyś na szpital szły czynsze o wartości 13 złp, ale identycznie jak ordynaria, $\mathrm{z}$ biegiem czasu zupełnie zanikły. Jeśli chodzi o zamieszkanie tych osób (wtenczas były to jedynie trzy staruszki), to w połowie XVIII stulecia korzystały one z dwóch budynków ulokowanych przy gościńcu, zbudowanych ponad 20 lat wcześniej za 400 złp. Do nich należał jeszcze ogród ${ }^{87}$.

O dwóch ostatnich szpitalach w Łukowej i Potoku archiwalia milczą. Z pojedynczych zapisek można wywnioskować jedynie, że działały one w XVII w. ${ }^{88}$ i że schronienie dla ubogich w Potoku spaliło się w $1636 \mathrm{r}^{89} \mathrm{~W}$ następnym stuleciu przytułek $\mathrm{w}$ Łukowej dysponował ogrodem wydzielonym przez plebana oraz czynszem (16 złp) od 200 złp zapisanych 23 VI 1739 r. przez tamtejszego rządcę ks. Kazimierza Osęckiego, kanonika chełmskiego i zamojskiego, zabezpieczonych na mieszczącym się przy rynku w Tarnogrodzie domu Żyda Szeji ${ }^{90}$. Tamtejsi potrzebujący utrzymywali się ponadto z jałmużny. Jedynie z jałmużny żyli z kolei ubodzy z Potoku. Nic nie wiadomo o ogrodzie, wzmiankowanym w 1646 r., podarowanym przez jakiegoś Marcina ${ }^{91}$. Domostwo szpitalne też nie przedstawiało się tam jakoś szczególnie. W Łukowej stało koło kościoła, miało dwie izby i sień. Dom ten opisano $w$,,podwalinach i ścianach zły i zgniły, a w dachu wielkiej reparacji potrzebujący". W Potoku szpital wybudowano przy drodze i składał się z ganku, dwóch izb i trzech komór ${ }^{92}$.

${ }^{87}$ AAPrz, sygn. 170, k. 7-7v, 15v.

${ }^{88}$ Ibidem, sygn. 64, s. 202; sygn. 158, s. 2099, 2136; W. Partyka, Opieka społeczna, s. 58-59, 92.

${ }^{89}$ AAPrz, sygn. 158, s. 2092. Z tego też względu datę zaproponowaną przez W. Partykę odnośnie pierwszej wzmianki o szpitalu w Potoku (przed 1646 r., s. 93), należy przesunąć na co najmniej przed 1636 r. Rozwiewa to też wątpliwości, co do istnienia tam przytułku w pierwszej połowie XVII w. (s. 48). Inna sprawa, że rzeczywiście nie wiadomo, czy po pożarze wzniesiono nowy budynek i dlatego w wizytacji z 1646 r. nie odnotowano jego zabudowań.

${ }^{90}$ AAPrz, sygn. 170, k. 57v-58; W. Partyka, Opieka społeczna, s. 126.

91 AAPrz, sygn. 64, s. 202; W. Partyka, Opieka społeczna, s. 48, 93, 119. Historyk ten podaje ponadto, że potrzebujący z tej wsi dysponowali półtora łanem, z czasem zamienionym na coroczne 50 złp. Dziwne, że tak dużego nadania nie odnotowały wizytacje, ale z drugiej strony trudno ustalić, kiedy ta darowizna miała miejsce. Autor w tej sprawie, powołując się na źródło z 1790 r., nie precyzuje szczegółów tej donacji.

${ }_{92}$ AAPrz, sygn. 170, k. 24v, 30-30v, 57v-58, 63v-64. 


\title{
Bractwa
}

Jednym z najważniejszych ogniw życia parafialnego były bractwa kościelne (fraternitas, confraternitas, archifraternitas). Kazimierz Kuźmak pisze o bractwach jako

\begin{abstract}
„Zrzeszeniach religijnych erygowanych formalnym dekretem przez władzę kościelną i pozostających pod jej zwierzchnością jako stała fundacja, mająca osobowość prawną, własną administrację oraz statuty regulujące strukturę, charakter i cele bractwa, a także sposoby ich realizacji. Celem bractw, twierdzi dalej badaczka, jest rozwój kultu publicznego w kościele, pogłębianie i zaktywizowanie chrześcijańskiego życia członków bądź prowadzenie określonej działalności religijnej lub społecznej”93.
\end{abstract}

Takie zrzeszenia działały też w omawianych tutaj parafiach. Najwcześniejsze źródła notują je w Tarnogrodzie pod rokiem 1598. Mowa tutaj o bractwie św. Anny. Drugie, literackie, również pochodziło $\mathrm{z}$ tego okresu ${ }^{94}$. Ich niejako uzupełnienie stanowiło, najpopularniejsze $\mathrm{w}$ diecezji przemyskiej, bractwo różańcowe powołane do życia 26 VI 1635 r. decyzją oficjała generalnego przemyskiego ks. Magnusa Nijowskiego ${ }^{95}$. Do XVIII stulecia dotrwały dwa z nich, św. Anny i różańcowe. Wizytacje tak bogate $\mathrm{w}$ różnorodne informacje milczą niestety na temat ich uposażenia. Wymieniono tylko skarbony brackie zainstalowane w kościele farnym.

Na początku drugiej dekady XVII w. z inicjatywy rządcy ks. Marcina Nagórki, kanonika przemyskiego i sandomierskiego, a także za pozwoleniem II ordynata Tomasza Zamojskiego, starosty knyszyńskiego oraz aprobatą władz arcybractwa w Warszawie, powstało jedyne w Łukowej bractwo św. Anny ${ }^{96}$. Dysponowało ono nieruchomością $\mathrm{w}$ postaci czterech zagonów pola, umiejscowionych w ćwierci roli plebańskiej zwanej „Makuchowskie” - którą zresztą wydzierżawiało plebanowi za 11 złp - oraz swoją skarboną w świątyni97.

${ }^{93}$ K. Kuźmak, Bractwa kościelne, [w:] Encyklopedia katolicka, t. 2, red. F. Gryglewicz, R. Łukaszyk, Z. Sułowski, Lublin 1976, kol. 1013. Zob. też: J. Flaga, Bractwa religijne w Rzeczypospolitej w XVII i XVIII wieku, Lublin 2004, s. 5-10.

${ }^{94}$ G. Klebowicz, Organizacja parafialna, s. 480.

${ }_{95}$ AAPrz, sygn. 158, s. 2508. Zob. też: H. Borcz, Bractwa religijne w kościołach parafialnych diecezji przemyskiej w okresie przedrozbiorowym, „Roczniki Teologiczno-Kanoniczne”, t. 28, 1981, z. 4, s. 82.

${ }^{96}$ H. Borcz, Bractwa religijne, s. 80.

${ }^{97}$ AAPrz, sygn. 170, k. 56v. 
Spośród tych konfraterni najbogatsze wydaje się być Bractwo Szkaplerzne NMP w Potoku. Datuje się je na 20 VII 1677 r., kiedy to ordynariusz przemyski Stanisław Sarnowski zatwierdził oficjalnym pismem jego funkcjonowanie ${ }^{98}$. Istotne jest to, że 14 II 1731 r. przydzielono go do nowo ufundowanej przez znanych już braci Grabińskich prebendy. Na majątek bracki składały się późniejsze, XVIII-wieczne donacje, związane z połączeniem $\mathrm{z}$ wymienioną wyżej prebendą. Dobroczyńcy przekazali na nią wtedy aż 5000 złp usadowionych na ich dobrach z rocznym czynszem 350 złp, a cześnik nowogrodzki Adam Wolski i jego żona Katarzyna w testamencie upoważnili wykonawców swojej ostatniej woli Franciszka Grabińskiego i Jana Drelinga do zabezpieczenia na ich nieruchomościach $1000 \mathrm{złp}$. W związku z tym drugim nadaniem wynikły pewne nieporozumienia między Grabińskim a Drelingiem, ale czynsz bez uszczerbku regularnie uiszczano. Żadnego pożytku nie miano natomiast z 5000 złp, gdyż w czasach Sierakowskiego nie płacono już przyrzeczonych wyderkafów. Bractwo czy raczej prebenda dysponowała też jedną ósmą pola zwanego „Kwasowska”, będącego między polami plebańskimi, a rolą chłopa dworskiego Macieja Bziczka. Podarował je w 1739 r. VII ordynat Tomasz Zamojski, starosta płoskirowski ${ }^{99}$.

Najmniej można powiedzieć o bractwie różańcowym w Krzeszowie, powstałym w $1643 \mathrm{r}^{100}$ Nie miało ono swojej fundacji, toteż trudno tu mówić o konfraterni w pełnym tego słowa znaczeniu. Niemniej nadano mu $200 \mathrm{złp}$ wraz z czynszem, ale nie przetrwało ono próby czasu, toteż w XVIII stuleciu, a może nawet wcześniej, zanikło ${ }^{101}$.

\section{Zamiast podsumowania}

Problematyka uposażeniowa parafii jest bardzo skomplikowana i aby zrozumieć mechanizmy jej działania potrzebne są jeszcze bardziej gruntowne badania źródeł kościelnych. Historycy zajmujący się dziejami staropolskiej diecezji przemyskiej, niemałego przecież obszaru i z największą liczbą parafii w stosunku do powierzchni (!) w całej archidiecezji lwowskiej, rzadko sięgają po te kopalnie informacji. Usprawiedliwieniem niewystarczającego wykorzystywania tych źró-

\footnotetext{
98 Por. H. Borcz, Bractwa religijne, s. 81.

99 AAPrz, sygn. 170, k. 23v - 24.

${ }^{100}$ Ibidem, sygn. 160, k. 108v; H. Borcz, Bractwa religijne, s. 80.

${ }^{101}$ AAPrz, sygn. 170, k. 7.
} 
deł są być może trudności w dostępie do tych materiałów. Niemniej bez nich, jakiekolwiek badania spraw kościelnych (gospodarczych, społecznych, architektonicznych) nie mają większego sensu. Dość powiedzieć o prawie ciągle nieznanych, badaczom rodzimym i nie tylko, aktach konsystorskich przemyskich. Odrobinę lepiej wygląda to $\mathrm{w}$ przypadku akt wizytacyjnych (zwłaszcza tych z połowy XVIII w.). Bez rozeznania tych źródeł, uczciwej analizy, każda publikacja poświęcona parafiom będzie mocno niepełna, a czasami wręcz nieprawdziwa.

Niniejszy artykuł stanowi jedynie przyczynek do dalszych badań, podsumowuje niejako dotychczasowe informacje oraz co najważniejsze, po raz pierwszy naświetla i omawia te zagadnienia, będące do tego czasu nieznane w historiografii.

\section{Summary}

\section{Roman Catholic Parishes of the Przemyśl Diocese in the Zamoyski Entail Estates in the Mid-18th Century}

The article presents the history and endowment of four parishes that make up the Roman Catholic Diocese of Przemyśl and are at the same time parts of the Zamoyski Entail estates, i.e. Krzeszów, Łukowa, Potok, and Tarnogród. The parish property included land (fields, gardens, orchards, ponds), own farms, corvée of the serfs (specified amount and so-called free service), tithes and poll tax (in grain or money). The study also presents the basis for the functioning of hospitals and fraternities. These institutions usually supported themselves from rents and small land apportionments.

KEYWORDS: Diocese of Przemyśl; Krzeszów, Łukowa, Potok, Tarnogród, Zamoyski Entail, Wacław Hieronim Sierakowski.

\section{Bibliografia}

\section{Źródła drukowane}

Rejestr poborowy ziemi przemyskiej z 1628 roku, wyd. Z. Budzyński, K. Przyboś, [w:] Polska południowo-wschodnia w epoce nowożytnej. Źródła dziejowe, t. I, cz. 1, Przemyśl-Rzeszów 1997. 
Statuta Ordynacyi Zamoyskiej od r. 1589-1848, Warszawa 1902.

Volumina legum, t. 2, Ab anno 1550 ad annum 1609, Petersburg 1859.

Zbiór dokumentów małopolskich, cz. 4, Dokumenty z lat 1211-1400, wyd. S. Kuraś, Wrocław 1969.

Zbiór dokumentów małopolskich, cz. 6, Dokumenty z lat 1386-1417, wyd. I. Sułkowska-Kuraś, S. Kuraś, Wrocław 1974.

\section{Literatura}

Ataman J., Akta wizytacji diecezji przemyskiej do końca XVIII wieku (w archiwum diecezjalnym w Przemyślu), „Archiwa, Biblioteki i Muzea Kościelne”, t. 1, 1960, z. 2, s. 32-44.

Baliński M., Lipiński T., Starożytna Polska pod względem historycznym, jeograficznym i statystycznym opisana, Warszawa 1845.

Bazan T., Zarys dziejów gminy Potok Górny 1574-2002, Leżajsk 2003.

Bazan T., Zarys dziejów gminy Potok Górny 1574-2002, Leżajsk 2003, [rec.] R. Bubczyk, „Res Historica”, t. 21, 2005, s. 173-176.

Borcz H., Bractwa religijne w kościołach parafialnych diecezji przemyskiej w okresie przedrozbiorowym, „Roczniki Teologiczno-Kanoniczne”, t. 28, 1981, z. 4, s. 77-89.

Burda E., Sierakowski Wacław Hieronim z Bogusławic h. Ogończyk (1700-1780), [w:] Polski słownik biograficzny, t. 37, z. 153, Warszawa 1996-1997, s. 306-313.

Czupryk R., Relacje unicko-łacińskie w świetle kanonicznych wizytacji dekanalnych (na przykładzie diecezji przemyskich obrzadku unickiego i łacińskiego w XVIII w.), „Prace Historyczno-Archiwalne”, t. 20, 2008, s. 27-36.

Depczyński W., Krzeszów nad Sanem, Tarnogród 1976 [mps].

Depczyński W., Parafia Tarnogród, „Nasza Przeszłość”, t. 51, 1979, s. 125-207.

Depczyński W., Tarnogród 1567-1967. Monografia historyczno-gospodarcza, Tarnogród 1970.

Flaga J., Bractwa religijne w Rzeczypospolitej w XVII i XVIII wieku, Lublin 2004.

Gliwa A., Kraina upartych niepogód. Zniszczenia wojenne na obszarze ziemi przemyskiej w XVII wieku, Przemyśl 2013.

Gloger Z., Encyklopedia staropolska ilustrowana, t. 2, t. 3, Warszawa 1972.

Główka D., Akta wizytacji kościelnych z wieków XVI-XVIII jako źródło do historii kultury materialnej: gospodarstwo wiejskie $w$ dobrach parafialnych $w$ archidiakonacie warszawskim, [w:] Szkice $z$ dziejów materialnego bytowania społeczeństwa polskiego, red. M. Dembińska, Wrocław 1989, s. 233-254. 
Główka D., Gospodarka w dobrach plebańskich na Mazowszu w XVI-XVIII wieku, Warszawa 1991.

Horn M., Skład zawodowy i rozwarstwienie majątkowe Żydów tarnogrodzkich $w$ świetle inwentarzy $z$ lat 1650-1686, „Biuletyn Żydowskiego Instytutu Historycznego w Polsce", t. 78, 1971, nr 2, s. 11-29.

Kammler M., Klucz, [w:] Encyklopedia historii gospodarczej Polski do 1945 roku, red. A. Mączak, t. 1, Warszawa 1981, s. 310.

Klebowicz G., Nowożytne wizytacje kościelne jako uzupetniające źródło w badaniach problemu zniszczeń i najazdów w XVII-wiecznej ziemi przemyskiej i sanockiej, „Rocznik Przemyski”, t. 51, 2015, z. 3, Historia, s. 165-176.

Klebowicz G., Organizacja parafialna diecezji przemyskiej obrzadku łacińskiego w XIV-XVI wieku, Lublin 2013.

Klebowicz G., Wezwania kościołów parafialnych w średniowiecznej diecezji przemyskiej, [w:] Felix indiget Amicis. Studia $z$ dziejów kultury duchowej i intelektualnej średniowiecza ofiarowane Profesorowi Krzysztofowi Ożogowi, red. W. Świeboda, M. Zdanek, Kraków 2016, s. 89-128.

Kowalski M., Uposażenie parafii w rzymskokatolickiej diecezji przemyskiej w XVIII wieku, Lublin, 2017 [mps].

Kus J., Miasto w czasach przedrozbiorowych, [w:] Dzieje Tarnogrodu, red. R. Szczygieł, Tarnogród 2006, s. 65-117.

Kuźmak K., Bractwa kościelne, [w:] Encyklopedia katolicka, t. 2, red. F. Gryglewicz, R. Łukaszyk, Z. Sułowski, Lublin 1976, kol. 1013-1016.

Litak S., Atlas Kościoła łacińskiego w Rzeczypospolitej Obojga Narodów w XVIII wieku, Lublin 2006.

Litak S., Akta wizytacyjne parafii z XVI-XVIII wieku jako źródło historyczne, „Zeszyty Naukowe Katolickiego Uniwersytetu Lubelskiego”, R. 5, 1962, nr 3, s. 41-58.

Partyka W., Opieka społeczna w Ordynacji Zamojskiej w XVII-XVIII wieku, Lublin 2008.

Rolle J., Zakłady dobroczynne i szpitale w dawnem województwie podolskiem, „Przegląd Lekarski”, nr 17, 1867, s. 131-132.

Sidorowska A. B., Klucz szczebrzeski Ordynacji Zamojskiej w XVII i XVIII wieku, Lublin 2009.

Surdacki M., Opieka społeczna w Polsce do końca XVIII wieku, Lublin 2015.

Surdacki M., Źródła normatywne kościelne jako podstawa do badań nad szpitalnictwem w Polsce przedrozbiorowej, „Roczniki Nauk Społecznych”, t. 18, 1990, z. 2: Pedagogika, s. 57-70. 
Szczygieł R., Lokacja miasta i jego dzieje do końca XVI wieku, [w:] Dzieje Tarnogrodu, red. R. Szczygieł, Tarnogród 2006, s. 45-63.

Szczygieł R., Lokacje miast w Polsce XVI wieku, Lublin 1989.

Szczygieł R., Ordynacja Zamojska wobec prób lokacji ośrodków miejskich przy jej granicach $w$ pierwszej połowie XVII w., „Studia Iuridica Lublinensia”, vol. 25, 2016, nr 3, s. 881-892.

Szumowski W., Galicya pod względem medycznym za Jędrzeja Krupińskiego pierwszego protomedyka 1772-1783, Lwów 1907.

Wiśniowski E., Kolęda-meszne-stołowe na ziemiach polskich. Problem rejonizacji, [w:] Kultura średniowiecza i staropolska. Studia ofiarowane Aleksandrowi Gieysztorowi w pięćdziesięciolecie pracy naukowej, red. D. Gawin, Warszawa 1991, s. 625-638.

Zarębska T., Tarnogród - przykład szesnastowiecznej urbanistyki polskiej, [w:] Zamość i Zamojszczyzna w dziejach i kulturze polskiej, red. K. Myśliński, Zamość 1969, s. 203-211. 